\title{
UV SENSING PROPERTIES \\ OF ZnO NANOWIRES GROWN ON GLASS BY RAPID THERMAL OXIDATION OF ZINC FILMS
}

\author{
I. Mihailova ${ }^{1}$, V. Gerbreders ${ }^{1}, \bar{E}$. Sl̦edevskis ${ }^{1}$, \\ A. Bulanovs ${ }^{1}$, V. Paškevičs ${ }^{2}$ \\ ${ }^{1}$ G. Liberts' Innovative Microscopy Centre, Daugavpils University, \\ ${ }^{1}$ Parades Str., Daugavpils, LV-5401, LATVIA \\ ${ }^{2}$ Department of Physics, Daugavpils University, \\ ${ }^{1}$ Parades Str., Daugavpils, LV-5401, LATVIA \\ e-mail: irena.mihailova@du.lv
}

\begin{abstract}
The nanostructured $\mathrm{ZnO}$ thin films were successfully synthesized by rapid thermal oxidation of metallic zinc films without catalysts or additives. On the surface of thin films the formation of $\mathrm{ZnO}$ nanowires was observed. In the work, the optical and electrical parameters and photoresponses of the obtained $\mathrm{ZnO}$ thin films were investigated. Nanostructured thin films of the type have a promising potential for the use in optoelectronics, sensor technique and biomedical sciences.
\end{abstract}

Keywords: zinc oxide nanowires, rapid thermal oxidation, photoresponse, $U V$ photodetectors.

\section{INTRODUCTION}

Zinc oxide is a transparent semiconductor with a wide band gap of $3.37 \mathrm{eV}$ and a high exciton binding energy of $60 \mathrm{meV}$ at room temperature (RT). Due to its great bond strength, good stability of excitons and excellent optical and piezoelectric properties, $\mathrm{ZnO}$ is a promising candidate for semiconductor materials, piezoelectric devices, photoconductors, optical waveguides, etc. [1]. Among various applications, $\mathrm{ZnO}$-based devices such as solar cells [2], field emission displays [3], UV photodetectors [4], and chemical and biological sensors [5, 6] can be mentioned.

The main goal of this research was to explore the possibility of making the UV photodetectors based on nanostructured $\mathrm{ZnO}$ thin films synthesized by rapid thermal oxidation of metallic zinc films. In the work, the transmittance spectra, the resistance dependence and the photoresponse of $\mathrm{ZnO}$ thin films were investigated. The time dependence of rise and decay curves under visible illumination was also studied. 


\section{EXPERIMENTAL}

The nanostructured zinc oxide thin films used in this study were successfully synthesized by rapid thermal oxidation of metallic zinc films. A thin layer of $\mathrm{Zn}$ was deposited onto glass substrates by magnetron sputtering to enhance the adhesion of the $\mathrm{Zn}$ films to be oxidized to the glass surface. After that, the zinc thin films were deposited by vacuum thermal evaporation at different rate $(0.28-15.95$ $\mathrm{nm} / \mathrm{s})$, with samples of the same total thickness $(\sim 700 \mathrm{~nm})$ of $\mathrm{Zn}$ thin films obtained. Next, a rapid thermal oxidation of the samples was performed at the same conditions - in a standard tube furnace under air atmosphere, where the samples were heated for $15 \mathrm{~min}$ at $530^{\circ} \mathrm{C}$. As a result, $\mathrm{ZnO}$ thin films with different concentration of $\mathrm{ZnO}$ nanowires (NWs) on the surface were obtained (Fig.3). The details of the preparation procedure have already been described in [7].

The surface morphology of the samples was studied using a TESCAN-VEGA $L M U$ II scanning electron microscope (SEM).

A Shimadzu MCP-2200 UV-Vis-NIR spectrophotometer was taken to examine the optical transmittance, reflectance and absorption of thin films over the wavelength range from 300 to $900 \mathrm{~nm}$.

To investigate the electrical parameters and the photoresponse of the nanostructured $\mathrm{ZnO}$ thin films, two $250 \mu \mathrm{m}$ wide copper electrodes were evaporated by magnetron sputtering at a distance of $500 \mu \mathrm{m}$ from each other on the surface of the thermally oxidized films (Fig.1). The photoresponsivity of samples was measured at RT and under one and the same atmosphere pressure. The samples were initially kept in dark until the dark current was stabilized. A $375 \mathrm{~nm}$ UV laser diode, a 405 $\mathrm{nm}$ Fabry-Perot laser diode and a $532 \mathrm{~nm}$ VERDI laser system were employed as the light sources for photoresponsivity measurements. The intensity of illumination was $\sim 1.5 \mathrm{~W} / \mathrm{cm}^{2}$.

The resistance dependence and the photoresponsivity of $\mathrm{ZnO}$ thin films were investigated using a 1/2 digit Picotest M3500A digital multimeter.

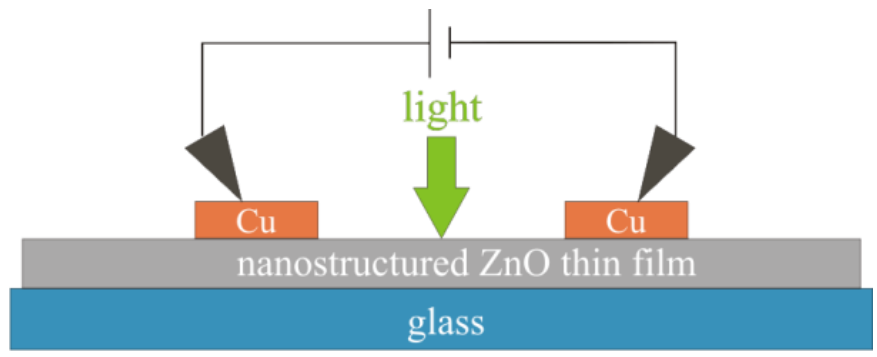

Fig. 1. Experimental setup for measuring the electrical parameters and photoresponsivity of the nano-structured $\mathrm{ZnO}$ thin films

\section{RESULTS AND DISCUSSION}

The morphology of the oxidized thin films was studied using SEM (Fig.2). As seen, the grown nanowires of $\mathrm{ZnO}$ are straight, with no branching, and distributed randomly on the whole surface. The $\mathrm{ZnO}$ NWs were counted, and the total area of the NW surface per $1 \mu \mathrm{m}^{2}$ was calculated (Fig.3). In the previous work 
[7], the concentration of $\mathrm{ZnO}$ nanostructures was investigated in dependence on the $\mathrm{Zn}$ film morphology and the annealing conditions in the open atmosphere.
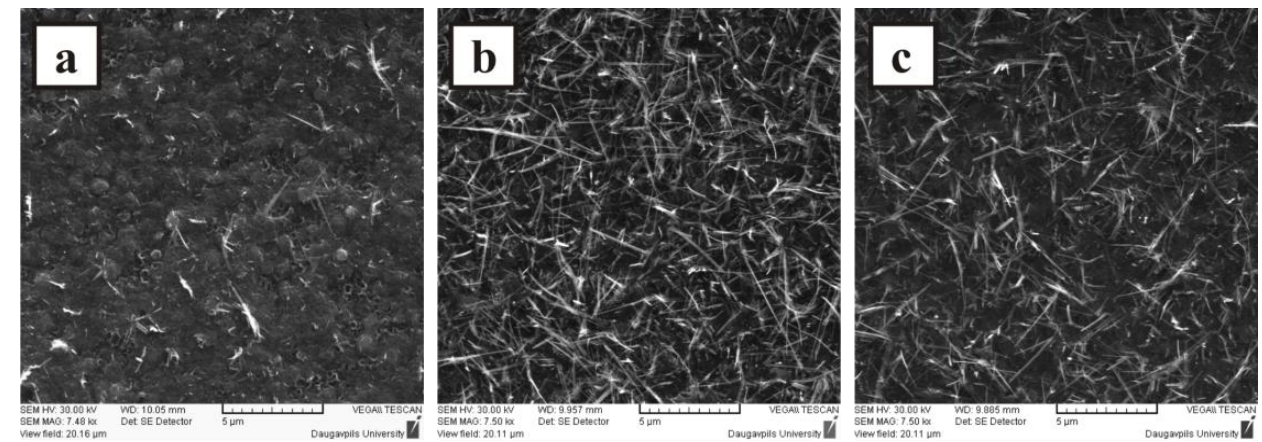

Fig. 2. SEM images of the oxidized thin films for the samples:

a) S1; b) S3; and c) S5.

As can be seen in Fig. 3, the greatest increase in the total surface area of $\mathrm{ZnO}$ samples can be achieved at the rates of thermal deposition of $0.32 \mathrm{~nm} / \mathrm{s}$ (S2) and $1.36 \mathrm{~nm} / \mathrm{s}(\mathrm{S} 3)$.

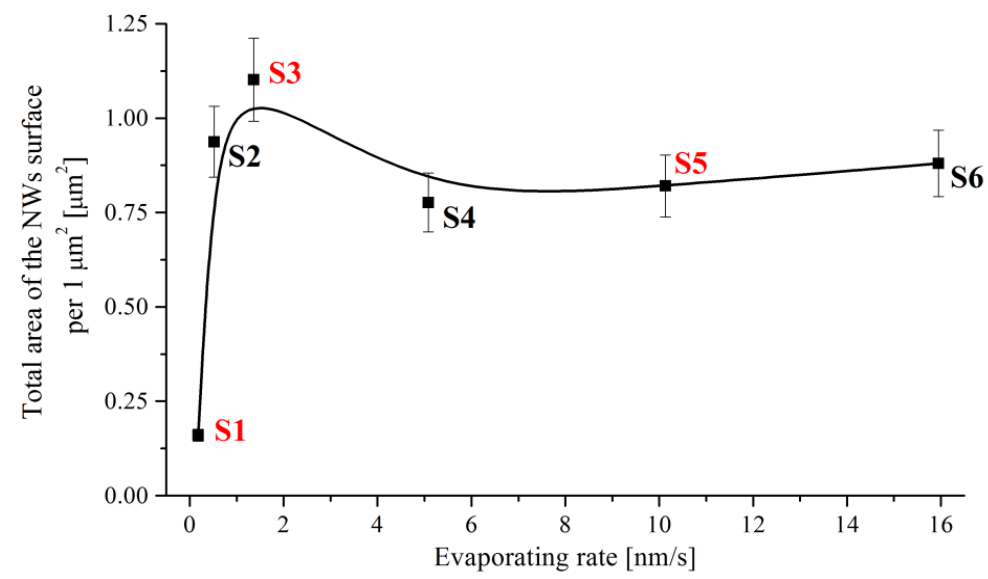

Fig.3. The total NW surface area per $1 \mu \mathrm{m}^{2} v s$. the thermal deposition rate [1].

The optical absorption spectra of $\mathrm{ZnO}$ thin films are shown in Fig 4. Zinc oxide exhibits high transmission in the visible region and absorption in the UV region. It is obvious that the intensity of absorption spectra is increasing with concentration of $\mathrm{ZnO}$ nanostructures on the surfaces of thin films. The absorption edge is between $350 \mathrm{~nm}$ and $400 \mathrm{~nm}$ for all $\mathrm{ZnO}$ thin films. It was observed that the absorption edge of the films shifts to a longer wavelength side as the concentration of NWs increases, which indicates a decrease in the band gap value.

In our previous work [7] it was shown that with the concentration of $\mathrm{ZnO}$ NWs increasing also the luminescence intensity in the UV region increases, indicating a structural improvement. The highest UV luminescence was observed for sample S3. 


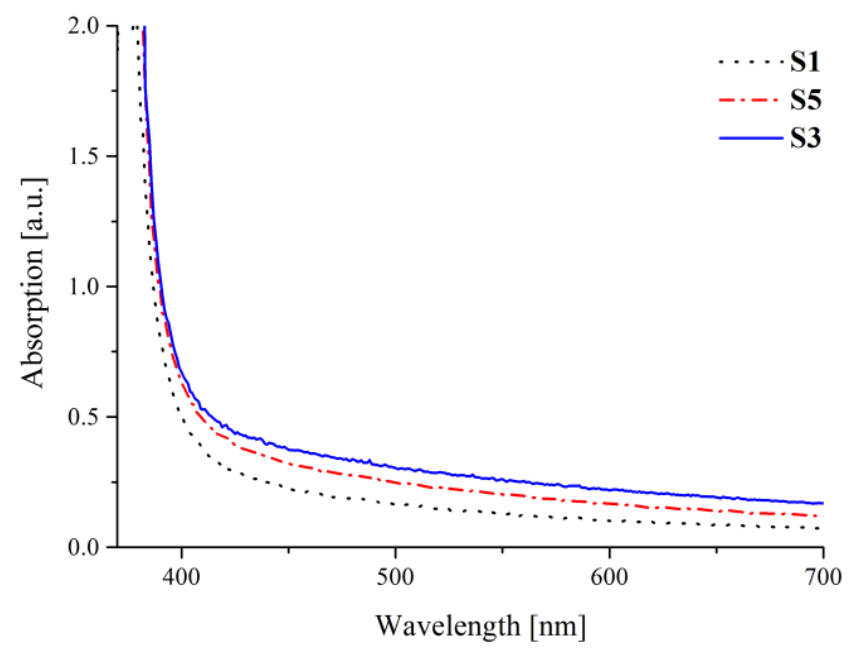

Fig. 4. Absorption spectra of oxidized $\mathrm{ZnO}$ thin films (samples S1, S3 and S5).

To investigate the electrical parameters of obtained $\mathrm{ZnO}$ thin films, the resistance was measured between two copper electrodes with a separation of 500 $\mu \mathrm{m}$ (Fig.1). Electrical conductivity $\sigma$ was determined from the resistance and other parameters of thin films. The photoresponsivity of the samples was measured in air at RT. The area between the electrodes was illuminated at the wavelengths $375 \mathrm{~nm}$, $405 \mathrm{~nm}$ and $532 \mathrm{~nm}$ with the radiation intensity $\sim 1.5 \mathrm{~W} / \mathrm{cm}^{2}$.

Analysis of the behaviour of illuminated nanostructured $\mathrm{ZnO}$ thin films in Fig. $5 a$ shows that their photoconductivity response can reversibly be switched 'on' and 'off' by switching the illumination of $375 \mathrm{~nm}$, the photoconductance of $\mathrm{ZnO}$ increases obviously compared to the dark. The illumination with the wavelength of $405 \mathrm{~nm}$ causes minor changes in the photoconductance of thin films. However, when the samples were exposed to visible light at $532 \mathrm{~nm}$ for $30 \mathrm{~s}$, no change could be observed in the photoconductance compared with the UV exposure. The results show that the photoconductivity of nanostructured $\mathrm{ZnO}$ thin films is more sensitive to the UV illumination as compared to visible light.
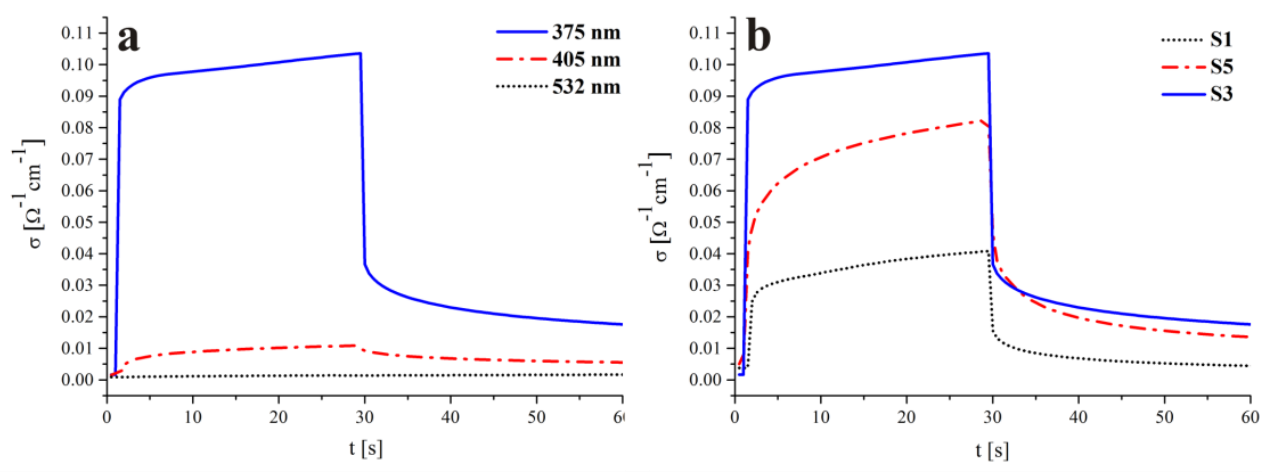

Fig. 5. The photoconductivity ON-OFF response of the samples:

a) S3, illuminated at $375 \mathrm{~nm}, 405 \mathrm{~nm}$ and $532 \mathrm{~nm}$;

b) S1, S3 and S5, illuminated at $375 \mathrm{~nm}$. 
The UV photoconductivity in $\mathrm{ZnO}$ thin films is generally attributed to either the bulk- or the surface-related processes. These latter are primarily governed by the adsorption and desorption of the chemisorbed oxygen on the surface of $\mathrm{ZnO}$. In the dark, oxygen molecules can be absorbed on the NW surface as negatively charged ions by capturing free electrons from the n-type $\mathrm{ZnO}$ nanowires, which will widen the depletion region under the surface and reduce the current:

$$
\mathrm{O}_{2}(g)+e^{-} \rightarrow \mathrm{O}_{2}^{-} \text {(absorbed species) }
$$

When the UV light was switched on, the photoconductance initially increased very fast due to the quick generation of electron and hole pairs as a result of absorbing the photons with energies higher than the $\mathrm{ZnO}$ band gap. Photogenerated holes migrate to the surface and release the captured adsorbed oxygen ions through the surface electron-hole recombination:

$$
\mathrm{O}_{2}^{-}+h^{+} \rightarrow \mathrm{O}_{2}(\mathrm{~g})
$$

The unpaired electrons accumulate gradually with time, resulting in an increase in the photoconductance. However, when desorption and re-adsorption of $\mathrm{O}_{2}$ reach an equilibrium state, the conductance would be saturated slowly. This relatively slow time scale indicates that the decay process is limited by oxygen readsorption [8-10].

When the UV light illumination was switched off, the initial decay in the photoresponse was very fast, which could be attributed to the bulk-related phenomena - to the recombination of free electrons and holes. Later, the conductance decreased slowly, which is attributable to the surface related process the slow process of re-adsorption of oxygen molecules. The presence of oxygenrelated hole-trap states on the surface prevents the charge-carrier recombination and prolongs the photocarrier lifetime.

We have every reason to think that a similar mechanism is realized in our samples. In Fig. $5 b$ one can see the time dependence of the photoconductivity ON-OFF response of samples S1, S3 and S5 illuminated at $375 \mathrm{~nm}$. It is obvious that this response depends on the concentration of $\mathrm{ZnO}$ nanostructures on the film surfaces. The highest photoconductivity was observed for sample S3, which has the largest total area of the surface of ZnO NWs per $1 \mu \mathrm{m}^{2}$ compared with other samples. The surface enlargement due to NWs may increase the number of electron-hole pairs generated by the light. Therefore, high surface-to-volume ratios of nanowires affect their photocurrent and UV sensing properties.

The linear fittings of the specific photoconductance response curve in a logarithmic scale (Fig.6) confirm the exponential time dependence following $\sigma=\sigma_{0}\left(1-e^{-\frac{t}{\tau_{g}}}\right)$ and $\sigma=\sigma_{0} e^{-\frac{t}{\tau_{d}}}$ for rise and decay, respectively. In the present research, both the growth and the decay of photoconductance follow two trends - a faster and - later - a slower one. Consequently, two time constants for each of them could be calculated [11,12]. 


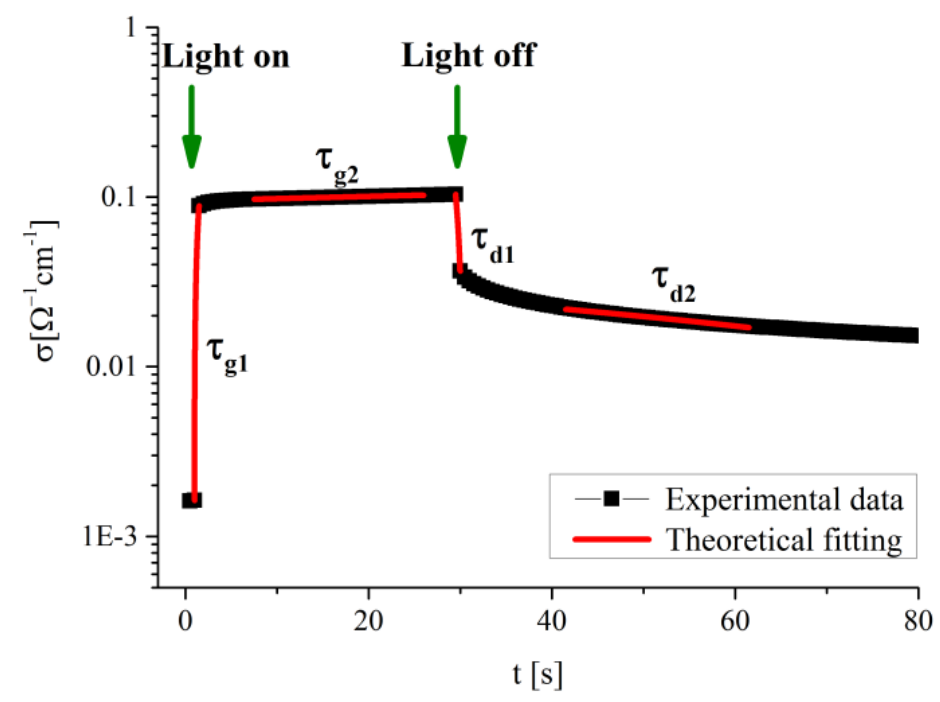

Fig. 6. Semi-log plot of the photoconductivity ON-OFF response of sample S3.

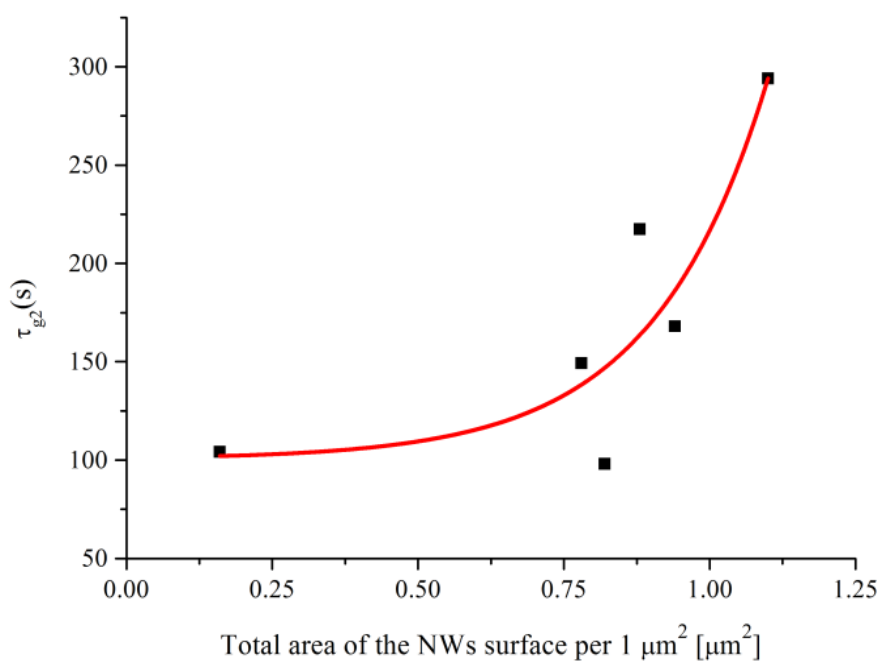

Fig. 7. Dependence of time constant $\tau_{\mathrm{g} 2}$ on the total area of NW surface per $1 \mu \mathrm{m}^{2}$.

Time constants $\tau_{g l}$ and $\tau_{d l}$ in Fig. 6 describe the fast bulk-related processes the photogeneration and the recombination of electrons and holes, respectively. From Fig. $5 b$ it is obvious that the increasing the concentration of $\mathrm{ZnO}$ NWs also accelerates the growth of the photoconductance induced by UV illumination. It could be suggested that enlarging the surface area increases the concentration of photogenerated electron-hole pairs. Thus, increasing the concentration of NWs decreases the time constant $\tau_{g l}$. To precisely determine the $\tau_{g l}$ and $\tau_{d l}$ more accurate measurements are needed. We have calculated and compared the values of $\tau_{\mathrm{g} 2}$ in a relatively slow time scale, when desorption and re-adsorption of $\mathrm{O}_{2}$ reach an equilibrium state and the current saturates slowly. From Fig. 7 it could be seen that increasing the concentration of NWs will also increase the $\tau_{g 2}$ values. At a larger 
surface-to-volume ratio of $\mathrm{ZnO} \mathrm{NWs}$ the surface area is enlarged for the reaction to take place, and the oxygen adsorption and desorption on the surface proceed easier. Due to the hole capture by oxygen atoms the total number of UV-generated charge carriers decreases; hence, the greater number of charge trap centres, the longer time is needed to raise the electrical conductivity by $e$ (Euler's number) times.

It is expected that higher concentration of thinner $\mathrm{ZnO}$ nanowires, which have higher surface-to-volume ratio, may further enhance the sensitivity of the relevant devices.

\section{CONCLUSIONS}

The conclusions to be drawn from the results obtained are as follows.

The electrical conductivity of the $\mathrm{ZnO}$ nanowires produced is extremely sensitive to UV light exposure, while the current remains almost unchanged when $\mathrm{ZnO}$ NWs are exposed to visible light. The photoconductivity ON-OFF response is also dependent on the concentration of $\mathrm{ZnO}$ nanostructures on the film surfaces. The highest UV photoconductivity is found for the sample with the largest concentration of $\mathrm{ZnO}$ NWs. The surface enlargement at the cost of NWs may raise the number of electron-hole pairs generated by the light. Therefore, high surface-tovolume ratios of nanowires affect their photocurrent and UV sensing properties. The increase in the light-induced conductance allows for reversible switching the nanowires between "off" and "on" states. Hence, these photoconducting NWs could serve as sensitive UV light detectors and optical switches. They also can be exploited in chemical and biological sensors, dye-sensitized solar cells, piezoelectric devices, etc. Furthermore, the synthesis process used in the work is rather cheap and simple, with a high yield, making possible a large-scale production.

\section{ACKNOWLEDGEMENTS}

This research was supported by ESF Project (agreement No. 2013/0029/ IDP/1.1.1.2.0/13/APIA/VIAA/029)

\section{REFERENCES}

1. Chuah, L. S., Hassan, Z., \& Tneh, S. S. (2009). Zinc oxide nanorods on porous silicon/silicon substrates. Journal of Optoelectronics and Advanced Materials, 11(11), 1637-1640.

2. Lee, Y.M, \& Yang, H.W. (2011). Optimization of processing parameters on the controlled growth of $\mathrm{ZnO}$ nanorod arrays for the performance improvement of solidstate dye-sensitized solar cells. Journal of Solid State Chemistry, 184, 615-623.

3. Ye, Z.Z., Yang, F., Lu, Y.F., Zhi, M.J., Tang, H.P., \& Zhu, L.P. (2007). ZnO nanorods with different morphologies and their field emission properties. Solid State Communications, 142(8), 425-428.

4. Yaoa, I.C., Tsengb, T.Y., \& Lina, P. (2012). ZnO nanorods grown on polymer substrates as UV photodetectors. Sensors and Actuators, A: Physical, 178, 26-31.

5. Carotta, M.C., Cervi, A., di Natale, V., Gherardi, S., Giberti, A., Guidi, V., Puzzovio, D., Vendemiati, B., Martinelli, G., Sacerdoti, M., Calestani, D., Zappettini, A., Zhac, M., \& Zanotti, L. (2009). ZnO gas sensors: a comparison between nanoparticles and nanotetrapods-based thick films. Sensors and Actuators, B 137, 164-169. 
6. Reyes, P.I., Duan, Z., Lu, Y., Khavulya, D., \& Boustany, N. (2013). ZnO nanostructure-modified QCM for dynamic monitoring of cell adhesion and proliferation. Biosens. Bioelectron, 41, 84-9.

7. Mihailova, I., Gerbreders, V., Tamanis, E., Sledevskis, E., Viter, R., \& Sarajevs, P. (2013). Synthesis of $\mathrm{ZnO}$ nanoneedles by thermal oxidation of $\mathrm{Zn}$ thin films. Journal of Non-Crystalline Solids, 377, 212-216.

8. Ridhuan, N.S., Abdul Razak, K., Lockman, Z., \& Abdul Aziz, A. (2012). Structural and morphology of $\mathrm{ZnO}$ nanorods synthesized using $\mathrm{ZnO}$ seeded growth hydrothermal method and its properties as UV sensing. PLoS ONE 7(11): e50405.

9. Kumar S., Kim, G. H., Sreenivas, K., \& Tandon, R. P. (2007). Mechanism of ultraviolet photoconductivity in zinc oxide nanoneedles. J. Phys.: Condens. Matter, 19, 472202.

10. Dwivedi, V.K., Srivastava, P., \& Vijaya Prakash, G. (2013). Photoconductivity and surface chemical analysis of $\mathrm{ZnO}$ thin films deposited by solution-processing techniques for nano- and micro-structure fabrication. Journal of Semiconductors, 34(3), 033001-5.

11. Dutta, M.,\& Basak, D. (2009). Multiwalled carbon nanotubes/ZnO nanowires composite structure with enhanced ultraviolet emission and faster ultraviolet response. (2009). Chemical Physics Letters, 480, 253-257.

12. Lee, J.S., Saif Islam, M., \& Kim, S. (2007). Photoresponses of ZnO nanobridge devices fabricated using a single-step thermal evaporation method. Sens. Actuators B: Chem., 126(1), 73-77.

\title{
TERMISKI OKSIDĒJOT Zn PLĀNĀS KĀRTIN̦AS IEGŪTU ZnO NANOADATU UV JUTĪBAS IZPĒTE
}

\author{
I. Mihailova, Vj. Gerbreders, Ē. Sl̦edevskis, A. Bulanovs, V. Paškevičs
}

Kopsavilkums

Ši darba galvenais mērķis bija izpētìt UV fotodetektora izgatavošanas iespējamību uz nanostrukturētu ZnO plāno kārtiņu bāzes, kas sintezētas termiski oksidējot Zn plānās kārtinas. Termiskās oksidešanas rezultātā tika novērota adatveidīgu $\mathrm{ZnO}$ nanostruktūru formēšanās uz kārtinu virsmas. Izpētītas iegūto paraugu optiskās un elektriskās īpašības, kā arī fotoreakcija. Tika konstatēts, ka iegūto nanostrukturēto ZnO kārtinu elektriskā vadītspēja ir ārkārtīgi jutīga pret UV starojumu, taču, apstarojot ar redzamo gaismu, strāva paliek gandrīz nemainīga. Kārtinu elektriskās vadītspējas fotoreakcija ir atkarīga arī no nanostruktūru daudzuma uz virsmas. Visaugstākā UV fotovadītspēja tika novērota paraugam ar vislielāko $\mathrm{ZnO}$ nanoadatu koncentrāciju. UV gaismas inducētais vadītspējas pieaugums l̦auj ZnO nanoadatas reversīvi pārslēgt starp stāvokḷiem "ieslēgts" un "izslēgts". Līdz ar to, šîs fotojutīgās nanoadatas var tikt izmantotas UV gaismas detektoros un optiskajos slēdžos. Šādas nanostrukturētas plānās kārtinas var tikt pielietotas arī ķīmiskajos un biologiskajos sensoros, pjezoelektriskajās ierīcēs, saules elementos utt. Turklāt, šādu nanostrukturēto $\mathrm{ZnO}$ plāno kārtinu sintēzes process ir salīdzinoši lēts un vienkāršs, dodot iespēju liela mēroga produkcijas ražošanai. 